Published in "International Review of Applied Economics 33(1): 51-70, 2019" which should be cited to refer to this work.

\title{
Surviving in the BRICS: the struggle of South African business in coping with new partners and investors
}

\author{
N. Wenzel ${ }^{\mathrm{a}}$, B. Freund ${ }^{\mathrm{b}}$ and O. Graefe ${ }^{\mathrm{a}}$

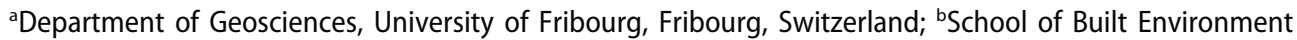 \\ and Development Studies, University of KwaZulu-Natal, Durban, South Africa
}

\begin{abstract}
The purpose of this paper is to improve our understanding of how South African economic actors react to the gradual entry of nonSouth African BRICS firms in their established business areas. Throughout the twentieth century, South Africa's trade and investment activities were conducted overwhelmingly with Western countries. However, the end of apartheid coincided with significant shifts as new players had a wider and growing presence. South Africa entering the BRICS alliance is symbolic of the change. Ease of entry into the South African economy has increased greatly. South African businesses in key subsectors in the mining and capital equipment industry have had to adapt to new players, and find space in new structures, value chains and initiatives. This paper presents the results of this research activity from the perspective of the South African political economy. Practice-oriented research investigated how six local companies forge new partnerships and how well South African firms adapt and cope with an altered and often unstable environment. It assumed that entrepreneurial activity is not autonomous but takes place within a larger organisational framework. Entrepreneurial activity facilitates the effective exploitation of particular niches and relationships with service providers.
\end{abstract}

\author{
KEYWORDS \\ South Africa; BRICS; mining \\ management: \\ entrepreneurship; Chinese \\ business relations; niche \\ management
}

\section{Introduction}

In 2018, BRICS as a formal association of four/five emerging economies (Brazil, Russia, India, China and South Africa, since 2011) enters its second decade of existence. The 10th BRICS Summit, an annual diplomatic meeting, is due in Johannesburg. South Africa is also finalising its preparations to take over the rotating leadership of the BRICS group for the second time in 2018. Following his election, the country's new President, Cyril Ramaphosa annouced his will to strengthen relations between South Africa and other members of the BRICS alliance.

In The Rise of the BRICS in Africa, Pádraig Carmody, a development geographer, argues that 'South Africa accommodates global and regional power interests on the continent, making it a "gregional" state and power' (Carmody 2013). The notion of a gregional power configuration exemplifies South African elites' aspirations in the way the country 'serves as 
a transmission belt for global forces to the rest of the continent'. This is key to grasping where the South African economy is positioned in the grand discussion over BRICS. After exploring the diverse interests and strategies of players from the individual BRICS nations, Carmody (2013) notes that South African interests in fact bolster Chinese big businesses' activities in Africa with impacts that remain unclear. The purpose of this paper is to improve our understanding of how South African economic actors react to the gradual entry of non-South African BRICS firms in their established business areas.

Carmody does not define the particular role of South African companies in the BRICS process (Draper and Qobo 2015). In addition, it is not clear how governments politically engaging in BRICS would promote more value-added exports and attract investment in minerals beneficiation or processing at source as would be desirable (Kaplan 2015). Instead, increased competition from BRICS firms, mainly with those from India and China, has become a practical challenge for many firms, notably in manufacturing (Kaplan 2015; Manufacturing Circle 2017). An understanding of how to engage economically with non-South African BRICS actors is pertinent for policy makers and private firms (Qobo 2010; Draper and Qobo 2015). In her criticism of suspect state-business relations, Catherine Grant Makokera $(2015,127)$ advances the argument earlier made by Qobo (2010) on the

'...need for the public and private sectors in South Africa to work together in order to develop further the economic diplomacy of the country. There is a clear potential to mutually agree on an approach that is both supportive of the economic development of the African continent and protective of the assets and access to profits of the South African business community' (Grant Makokera 2015).

In other words, how do South African firms succeed or fail with their strategies of internationalisation against increased international competition (Barnes and Morris 2008; Morris and Barnes 2014; Verhoef 2011)? The present study explores novel inter-firm cooperation practices and examines how the activities of economic actors from the other BRICS members fit into the contemporary South African economy. The study could reveal neglected factors in what is often described as a rush for resources in sub-Saharan Africa or in the contested international market for capital goods and services. Moreover, there has been little academic attention devoted to the question of how a BRICS strategy influences South African economic policies (Çakir and Kabundi 2017; Draper and Qobo 2015) or on how enterprises engage in competitive or collaborative economic practices.

We consider the salience of new and still largely bilateral engagements and their effects on South Africa's economic transition. This calls for a study of practices and meso-level effects rather than purely macroeconomic factors. Here, we can combine studies of inter-linking in a post-Western world order globally with organisational studies of inter-firm relationships, where the stable hierarchies (Chandler 1977) once described have often tumbled. This study focuses on what we identify as entrepreneurial practices of South African managers, very diverse but separate from the very large shareholder value-driven multinational South African companies (Verhoef 2011). These multinationals (BHP Billiton, AngloGold Ashanti, Sasol or MTN) seek the attainment of economic goals through 'go-it-alone diplomacy' in which 'flag follows trade' (Valsamakis 2012). 
Our conceptual foundation does not concentrate on the macro issues of inter-BRICS economic relationships and their effects on development processes in Africa but rather on a meso-level where socio-economic linkages and collaboration are exercised. Emerging questions include asking how the diverse private businesses perceive their role in South Africa's aspiration to become a gateway for non-South African BRICS business partners and investors into Africa. What does it mean to maintain a competitive advantage in such an environment and to create valuable and sustainable synergies? Which kind of power relations would be acceptable to South African executive teams in pursuit of what BRICS state elites have often casually labelled a 'win-win partnership'? Where are the African voices? Are the business voices the same as the government ones?

Researchers from the Trade Law Centre for Southern Africa in Stellenbosch have suggested that both South African diplomatic and business elites hoped that the BRICS process would be practically beneficial with new opportunities of expanding and diversifying export markets. State actors hoped that it would be supportive to broader economic growth. The South African economy was expected to attract investment in local minerals beneficiation or processing (and job creation at source), and in turn new greenfield investments beyond mere portfolio speculations. Business executives anticipated chances of promoting value-added exports into new markets in the prospering BRICS. They hoped that the high entry barriers to imports from non-South African BRICS countries would also be lowered for BRICS partner firms (Fundira 2011; Sandrey and Jensen 2012).

The following focal questions guided the field research on strategies and practices in a carefully selected group of six South African corporations in the mineral resources supply chain. How do such corporate executive teams ${ }^{1}$ rethink strategies for corporate development in a rapidly changing global environment specifically shaped by the opening up of the economy post 1994, the non-South African BRICS countries' increased engagement on the African continent via South Africa, and the volatility of the mineral resources industry? In what way then do teams of South African corporations implement their strategies and perform practices in this context?

\section{Materials and methods}

\subsection{Ethnographic research method}

Economic geography can contribute to the demarcation and deepening of our understanding of 'agency' and identifying essential practices that manifest at the inter-firm level (Jones and Murphy 2011). A relational practice-orientated approach developed in this discipline was adopted when analysing the perspectives of the South African economic actors. Instead of focussing on individual entrepreneurs and entrepreneurialism, this study's investigation embraced teams. The focus was on identifying repeated but improvised social practices that can result in desired economic outcomes in space and time. The key factor is the direct link or links between the practices under study, their outcomes, and their socio-economic meanings. As 'practice remains a rather loose and literal idea', Jones and Murphy $(2011,376)$ propose the use of 'practice' for '... effectively conceptualizing the relationship between, on the one hand the significance 
and meaning of micro-social actions and, on the other, larger-order structures, such as institutions, social class or culture'. The effects, they argue, can be profitable, although not necessarily stable, outcomes. The causal practices specify meaning through their effects. Effects such as infrastructure improvement, improved competitiveness, synergic innovation, attractiveness to partners, and power relations in buyer's markets are tangible and may be measured or observed within and beyond the firm.

It is precisely practices, arrangements and their significant effects (Jones and Murphy 2011; Schatzki 2006), which we can employ empirically to describe and understand agency better. Practices involve multiple logics, which are potentially in conflict, about what is at stake in the competition for valued desiderata (status, power, resources) in a social field. Agency here is not a synonym for practices but rather a specific capacity to act or interact based on organisational memory, past experiences, and present and future expectations of an executive team. Understanding particular power relations, conflicts and hierarchies are preconditions for exercising effective agency.

Ethnographic field research methods, including in-depth interviews and non-participatory observations were conducted using a multiple-case study. A purposive sampling method covered the South African industrial sub-sectors, which form the backbone of the transforming economy, and which hold considerable comparative advantages in business on the African continent. The stable criteria applied in selecting firms ranging from small to large, whose principal business location is Johannesburg, were (1) at least two years in a business partnership with actors from other BRICS nations, (2) a significant interest in establishing or experience in attracting a shareholder from the BRICS, (3) a significant interest in continental African markets and (4) agreement to participate in longitudinal research enquiries for at least two years. A larger study (Wenzel Forthcoming) focusses on six private South African companies, as described in Figure 1. Forty-seven focused narrative in-depth interviews supplemented with informal discussions and observations were conducted with managers and officials in the companies in Johannesburg from February to April 2013 and from January to March 2014. These enabled an appraisal of what we characterise as entrepreneurial situations including internal strategy meetings or negotiations with customers, suppliers or potential partners for the purpose of creating joint ventures. Confidentiality regarding respondents' and their firms' identities was agreed with respect to the publication of

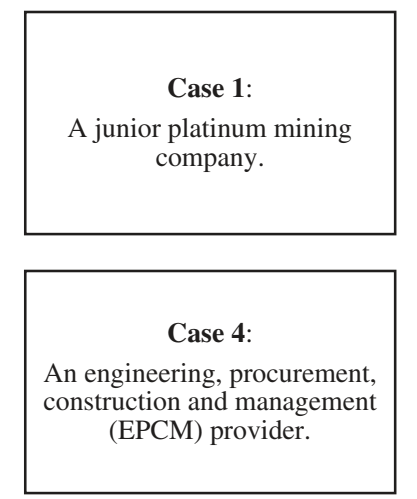

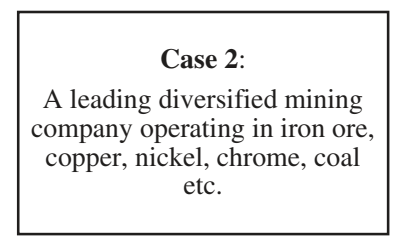

Case 5:

An original equipment manufacturer (OEM) (heavy vehicles) that supplies mining exploration and infrastructure construction companies.
Case 3:

A minerals freight and logistics company operating in chrome, manganese, and coal.

\section{Case 6:}

A components manufacturer (fastening systems) that supplies heavy industry and mining.

Figure 1. Six case studies of companies operating in diverse sectors of mining and manufacturing. 
data that would be sensitive to existing or potential competitors. The strength of the data set lies in the level of detail in the information obtained. The methodology's objective was to ensure the transferability of the study to similar research contexts rather than to generalise about the economy under study at present.

This paper presents detailed evidence from the first three cases. Cases Four and Six have been discussed elsewhere (Wenzel 2014, 2016). The three case studies presented initially here function within what Fine and Rustomjee (1996) have termed a MineralsEnergy Complex (MEC). This systematic orientation has remained dominant in contrast to economic mixes that might emphasise building domestic markets, producing consumer goods or competing internationally for exports. We adopt this perspective and describe systematic agency within its confines.

\section{Results}

\subsection{The South African economy in transition: new volatility in mining and BRICS players}

'South Africa can no longer rely on being the default entry point for foreign investment into the African continent. Now, more than ever, there is a unique opportunity to secure significant economic transformation' (Manufacturing Circle 2017, 6).

This paper explores how South African entrepreneurial teams cope with a rapidly shifting and challenging economic environment through an ethnographic research process using terms that have become significant recently for the discipline of economic geography. However, before discussing the research and its conclusions, we consider in this section some key aspects of that environment.

\subsubsection{Stable oligopolistic power relations in the past}

Throughout the twentieth century, South Africa's trade and investment relationships were predominantly with Western countries, particularly Britain. This reflected economic power in the world as well as South Africa's colonial history. Afrikaner nationalists were eager to reduce British influence. They also strongly supported the drive, already evident in the last premiership of J.C. Smuts, to develop heavy industry via the creation and development of parastatals. As mines-related capital on the Johannesburg Stock Exchange (JSE) was British oriented, the parastatals relied partially on loans from European banks during the heyday of apartheid.

South Africa's exports were dominated by gold; it was the source of most of the socalled free world's supply of gold. After the Bretton Woods Agreement was signed in 1944, the price of gold was effectively stable and predictable. The South African industry expanded based on a protected home market and was dominated by oligopolies in major lines of business, which created a basis for stable and considerable growth figures (Gelb 1991, 4). This stability lent itself to the replication of familiar structures and a growing bureaucratisation of management-led capitalism. Thus, it was similar to corporate structures in the major capitalist countries, starting with the USA. Alfred Chandler, following in the footsteps of writers such as Coase and Berle, highlighted a 'managerial revolution' where a hierarchical, professionally trained bureaucracy made 
the key decisions in a predictable and structured way for an economy dominated by big corporations (Chandler 1977).

In 1970, South Africa exported 1000 tonnes of gold, an unprecedented high point. However, not long afterward, the global economy began to change in ways that were unfavourable and unpredictable. South Africa's economy lurched into a crisis throughout the 1980s with 'stagnation in output growth; inflation entrenched at over 13\% per annum; a weak rand; a permanent decline in foreign exchange reserves; and historically low personal savings ratio'. This resulted in a legacy of economic problems in the 1990s (Gelb 1991, 1).

\subsubsection{South Africa's transition in relation to BRICS growth}

With the end of apartheid, the South African state moved to privatise and open up the economy very dramatically (Freund 2013; Terreblanche 2012). Ease of entry into the South African economy has increased greatly; old economic partners and investors have either withdrawn or lost dynamism, as the case studies below will demonstrate. Twenty years later, Gelb's tone was more positive but with serious preconditions. In his view, 'the core feature of our macroeconomic policy over the past decade and a half was based on the implicit assumption that if we got high marks on financial investors' good behaviour chart, we would be rewarded with high economic growth' (Gelb 2010, 58). However, this has proven untrue (Bhorat, Cassim, and Hirsch 2014; Black 2014; Hirsch 2005; STATSSA 2016).

The reasonable post-1994 recovery led to growth during the international boom in minerals and other raw materials, notably feeding into spectacular Asian growth and imports. However, after the 2008 crisis, figures showed instability and slow growth in most years (STATSSA 2016). Between 1994 and 2012, the average growth of real GDP reached 3.2\%. South Africa's real GDP for 2016 was nearly stagnant following sluggish increases of $2.2 \%$ in 2013, $1.5 \%$ in 2014 and $1.3 \%$ in 2015. Current assessments suggest that in 2017 only $1.3 \%$ was attained and the early estimates for 2018 actually proposed a decline for at least the first quarter. Domestic export production has remained comparably weak, undiversified and capital-intensive (Kaplan 2015; Makgetla 2011; Rodrik 2008). Critical writing has stressed the lack of skills, partly due to a brain drain, the skewed structure of South African industry, and assessed overall sluggishness, notably when compared to other middle-income economies (Kaplan 2015; Tregenna 2008). One result is that industry itself has remained tied to domestic mining and energy provision activities (Fine and Rustomjee 1996).

Yet sluggishness has been accompanied by considerable shifts in the business world. The opening of the economy under these circumstances has also resulted in the breakdown or reconstruction of the dominant economic linkages that prevailed in the past. Finding new linkages or establishing them has become very critical. South African businesses have had to adapt to new players and find space in new structures, value chains and initiatives. A consequence of this change has been the South African entry into the BRICS alliance. In the past five years, the dynamism of BRICS has largely been confined to China and India, and even China is no longer growing at the breakneck pace of a decade ago. Nevertheless, BRICS, as the hallmark of the present practiceoriented investigation, is still relevant in the context of a changing global environment. According to Bohler-Muller and Kornegay (2013, xxvi): 
Indeed, the original creation of the notion of a 'BRIC' grouping of emerging market economies by Goldman Sachs, as an investment marketing 'brand' for asset fund managers, had already given BRIC-turned-BRICS a level of profile not shared by other non-Western multilateral groups, such as IBSA for example. However, the political launching of the BRIC forum as a revisionist reform vehicle for forging change in the global economic and financial architecture has elevated this Wall Street 'branding' to a new level that has attracted global attention - and criticism (Bohler-Muller and Kornegay 2013).

Traders and end-users from China and the other BRICS members drove the commodity super-cycle of the last decade. Tables 1 and 2 present statistics with regard to South Africa in relation to other BRICS countries in 2016. The statistics display a highly heterogeneous set of countries pursuing economic growth over the past three decades.

BRICS also alludes to the looming importance of South African enterprises in new international value chains and to actual current issues that affect it. South African greenfield investments remain the lowest in BRICS, especially low when compared to China and Russia (Naudé, Szirmai, and Haraguchi 2015, 460-461). This is despite highly favourable returns on capital invested in South Africa and a comparably open economy (Bhorat, Cassim, and Hirsch 2014, 7). Yet South Africa retains significant interest from its BRICS partners. Currently, South Africa is the second-largest African investment destination for China behind Nigeria. It has served as a gateway for Chinese investment in Africa, especially in southern Africa (Mao 2017).

A closer look at relations with Asian players, in particular, reveals the South African mining industry's enduring significance as well as its weaknesses. Let us consider the big three items: gold, platinum and coal. South Africa's Witwatersrand Basin remains the world's largest gold resource (Chamber of Mines 2016). Having reached depths of $4,000 \mathrm{~m}$, South African deep-level gold mines recorded the highest production costs globally, with USD 1,035 per ounce in 2016, while the world average was USD 818 per ounce (Statista 2018). Added to the challenge of potentially

Table 1. BRICS members' individual macroeconomic performance in 2016.

\begin{tabular}{lcccc}
\hline & $\begin{array}{c}\text { GDP (million current } \\
\text { US\$) }\end{array}$ & $\begin{array}{c}\text { GDP per capita (US\$, } \\
\text { 2014-2016) }\end{array}$ & $\begin{array}{c}\text { Current account } \\
\text { balance (\% GDP, } \\
2016)\end{array}$ & $\begin{array}{c}\text { Trade (\% GDP, } \\
\text { 2014-2016) }\end{array}$ \\
\hline Brazil & 1798622 & 9874 & -1.3 & 12.1 \\
Russia & 1326015 & 10946 & 1.7 & 24.3 \\
India & 2256397 & 1645 & 0.9 & 24.0 \\
China & 11218281 & 7995 & 1.8 & 20.0 \\
South & 294132 & 5818 & -3.3 & 31.2 \\
$\quad$ Africa & & & & \\
\hline
\end{tabular}

Source: WTO.org, author compilation.

Table 2. BRICS members' individual ranks in world trade in 2016.

\begin{tabular}{lcccccc}
\hline & $\begin{array}{c}\text { Merchandise trade } \\
\text { exports }\end{array}$ & Imports & $\begin{array}{c}\text { Trade of commercial ser- } \\
\text { vices exports }\end{array}$ & Imports & $\begin{array}{c}\text { Share in world total } \\
\text { exports }\end{array}$ & $\begin{array}{c}\text { Share in world total } \\
\text { imports }\end{array}$ \\
\hline Brazil & 25 & 28 & 32 & 21 & 1.2 & 0.9 \\
Russia & 17 & 24 & 25 & 18 & 1.8 & 1.2 \\
India & 20 & 14 & 8 & 10 & 1.6 & 2.2 \\
China & 1 & 2 & 5 & 2 & 13.2 & 9.8 \\
SA & 38 & 34 & 49 & 46 & 0.5 & 0.6 \\
\hline
\end{tabular}

Source: WTO.org, author compilation. 
unprofitable current gold prices are wage pressures and increased competitive international production. Table 3 illustrates how local gold production in metric tons has significantly declined since 2012 , so that sales have fallen by $40 \%$. Only about $5.3 \%$ of the new worldwide supply was gold from South Africa by 2013 and the gold sector's contribution to the mining GDP has reduced considerably over the past decade (Minerals Council 2018a). This South African trend differs considerably from other now larger gold producing countries, ${ }^{2}$ in particular China, which ranks at the top. The new reality is that emerging players from China, Brazil and Russia have increased their annual gold production since 2010. China and Russia are key rivals. Anglo Gold Ashanti, the third largest producer in the world, is taking steps to 'ensure the viability of our remaining operations' according to a Johannesburg spokesman. The mines face 'systematic challenges' including declining output, increasing depth and cost escalations (Bloomberg, 2017). Yet, gold exports still account for $17 \%$ of South African mineral export income.

South Africa holds the world's largest known source of the six elements comprising the so-called platinum-group metals (PGM) (Chamber of Mines 2016; Misra 2000). Large mining houses are 'the majors of the sector, and responsible for producing up to $80 \%$ of the world's PGM supplies' (Minerals Council 2018b). However, Chinese companies have become the main traders and end-users. They drove the latest boom in PGM prices and the consequent development of mines from the mid-1990s. In the present study, the effect of China's expanding demand for platinum on South African mining firms is very relevant. In contrast to the decline in gold output by 63\% between 1994 and 2009, a boom in PGM prices and the associated mine development took off in the mid-1990s. By 2000, 'the total sales value of the PGMs eclipsed those of gold,' indicating a switch to the 'new dispensation's primary export and leading mineral stock' (Capps 2012, 78).

Coal also became a valuable export commodity from South Africa to China and India during the recent commodity super-cycle when prices peaked between USD 130 and USD 140 per ton in 2011 (Chamber of Mines 2015). A 6\% market share of global exports puts South Africa sixth in the list of coal-exporting nations (Chamber of Mines 2016). Chinese demand has since fallen off as Chinese production expands. However, new private power producers from India have increased demand for high-grade thermal coal. India, therefore, became the largest importer of South African coal (35.1 million metric tons and $46.6 \%$ of the total volume). The situation changed rapidly yet again as dollar coal prices and export volumes fell in 2015 (Chamber of Mines 2015). Looking at all three minerals, volatility with dramatic rapid price and demand shifts are being accompanied by significant BRIC partner activities as investors, customers and competitors. ${ }^{3}$

Table 3. Selected BRICS-countries' mines' global production of gold from 2010 to 2017.

\begin{tabular}{lcccccccc}
\hline & 2010 & 2011 & 2012 & 2013 & 2014 & 2015 & 2016 & 2017 \\
\hline SA & 189 & 181 & 160 & 160 & 152 & 145 & 150 & 145 \\
China & 345 & 362 & 403 & 430 & 450 & 450 & 455 & 440 \\
Brazil & 58 & 62 & 65 & 71 & 80 & 81 & 80 & 85 \\
Russia & 192 & 200 & 218 & 230 & 247 & 242 & 254 & 255 \\
\hline
\end{tabular}

Source: statista.com, author compilation. 


\subsection{Shifting structures: the urgent need for new and clear-cut strategies}

The changes in the external environment of the sample corporations have forced executive teams to rethink their orientation towards their businesses' critical future success factors and thus, develop new strategies or rethink existing ones. In this process, corporations' executive teams define for themselves competitive advantages according to how they perceive the interests, roles and powers of other players in future market developments. Defining a clearcut strategy is thus based on the teams' recognition of their increasingly unfavourable position acting as price takers against strong end-users. Moreover, new conceptions push towards stronger and better defined collaboration with the new end-users in Asia generating conditions for specific types of competitive agency (Wenzel Forthcoming).

Across the multiple case studies, the revised strategies can be grouped according to their effect on the companies' survival. In reality, these strategies do not necessarily stand alone but are interrelated (Figure 2). Longitudinal in-firm observations of strategising during peak, mid and trough commodity cycles notably reveal that executives have neither considered moderating profit margins nor reducing employment. More relevant to devising strategies, in particular with regard to adding value, are acute shortages in appropriately skilled engineers able to act with entrepreneurial acumen, as well as struggles with communication capacity often needed to engage with the new actors from the other BRICS and create synergies from new forms of collaboration.

\subsection{Shifting structures: BRICS players as new collaborators}

To enter and grow presence and market share in new locations, the majority of South African executives studied considered investors from non-South African BRICS

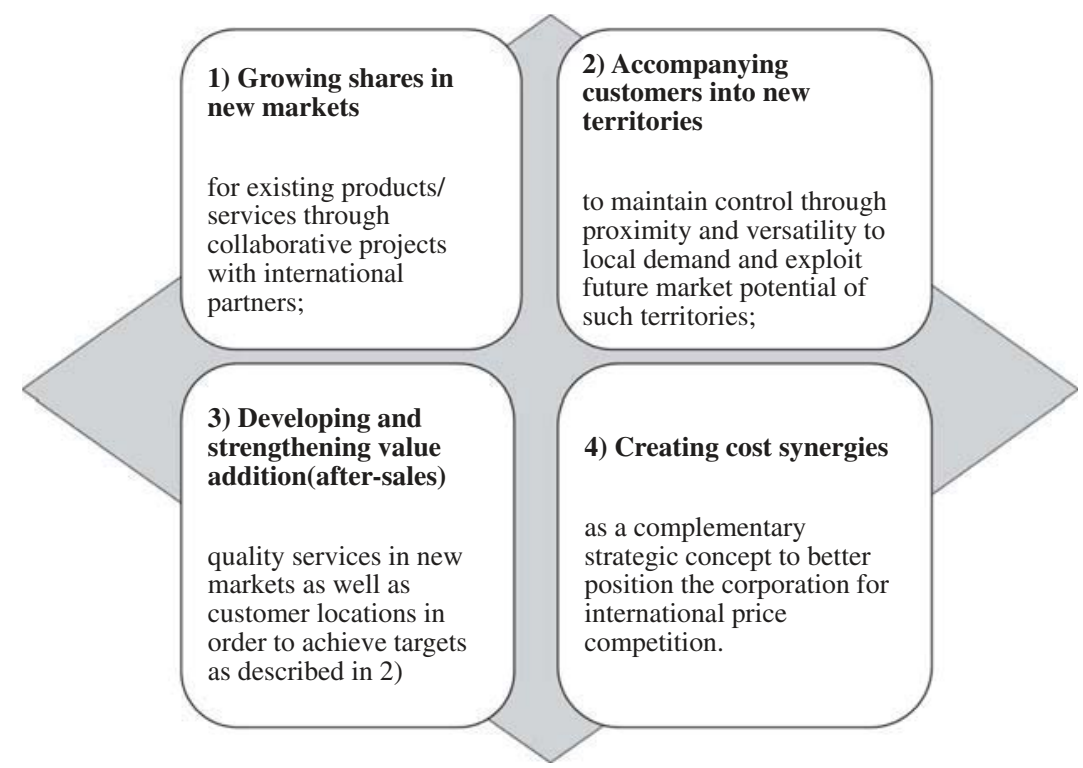

Figure 2. Four sets of strategies and associated targets to ensure survival of companies across the multiple-case study. 
economies as potential alternatives to their customary Western partners. They began to strategise and contemplate new mining projects once the sanctions era came to an end and before the BRICS pact existed (Wenzel 2014; Wenzel, Graefe, and Freund 2013). South Africa's entry into the BRICS alliance in December 2010 was considered symbolic rather than a step into the unknown.

Senior executives from Cases One and Two, both Johannesburg Stock Exchange (JSE) listed minerals and metals producers, represented companies highly dependent on both FDI and a stable international demand pattern and they acknowledged increasing options to leverage long-term resource interests from other BRICS countries elsewhere in Africa. In Case One, an opportunistic rationale and resultant survival strategy was pivotal in a very specific context and at a specific period in the company's life cycle. The founding executive team struggled to sustain a capitalintensive platinum exploration project in the midst of the financial crisis. The South African team stuck with their plan to bring a junior platinum mine on stream that was expected to employ more than 3,000 people. Initially, the well-timed financing strategy for investment had followed the model of 'business as usual' until the global financial crisis hit the Western economies:

...We had investors from all over the world. (...) And we were ahead of schedule, about a year ahead of schedule and lower in budget. So technically it was a great project and financially it was a great project. And at that point the company got listed and was about to go out and raise money on the international market. Then we got the feasibility study in June of 2008 ...But there were bureaucratic problems in the Department of Minerals and Resources. (...) There is no sense of urgency as to the fact that you are trying to build a billion dollar mine and to bring it on stream and that will employ 3.5 thousand people!

It was September 2008 when Lehman Brothers [folded]... it was game over. We still had not been given our mine permit back. And so that cost us effectively a billion dollars and three years of delay in the project as a result. And when Lehmann Brothers collapsed, my Western finance disappeared! Just evaporated! (Former senior executive, Case One mining company, Johannesburg, Personal communication, April 2013).

The team then had to think outside the box to identify a reliable and feasible financing alternative:

(...) The way that the platinum market works is that about $90 \%$ of platinum mined is sold on contract to Western (including Japan [sic]) companies. And 10\% of the production is sold on the spot market. And the Chinese who were the largest users of platinum were reliant on buying their platinum on the spot market. There you have got a very, very volatile pricing bearing in mind the relative high stability in Western contracts! (Former senior executive, Case One mining company, Johannesburg, Personal communication, April 2013).

The former senior executive of this company summarised what we term an 'opportunistic type of agency' that leverages the conditions of high uncertainty. In this case, the collapse of secure Western finance suppliers and shareholders led to negotiations with a Chinese consortium resolved within a month:

And in October 2008 I got onto a plane and I went to China, to Beijing, and I started to negotiate with the Chinese. The Chinese at that time had just passed the US as being the 
biggest world [automobile] manufacturer. They've subscribed to EURO5 environmental emission standards [thus desiring platinum catalytic converters]. They have got huge general environmental problems, they produce a very large part of the world's LCD screens and they have got a huge demand for jewellery. So as a market, China is significant... (Former senior executive, Case One mining company, Johannesburg, Personal communication, April 2013).

This visit to Beijing was a pioneering endeavour. It was an experiment in adjusting to the structural order of platinum markets with the support of large eager clients. The collaborative practices that followed in the coming years became possible due to a rapid shift in strategy towards a strong end user (Wenzel Forthcoming). It was a new and pragmatic 'secure platinum supply' strategy to ensure survival of the project. The actor first alerted members of the potential Chinese consortium about the situation and the context of the emerging financial crisis of 2008/2009. Chinese state-owned economic actors, although accounting for the biggest platinum demand, had not yet become dominant players in the ordering of the platinum markets. The team's effort to find new partners and investors resulted in the initiation of a new mine due to be commissioned in 2018, two years earlier than projected. Case One exemplified entrepreneurial methods for creating and actualising opportunities (Hjorth 2012; Sarasvathy and Venkataraman 2011).

The executive team realised that they needed to anticipate abrupt changes to solve problems as they sought suitable partners, whether clients, shareholders or governments. Most sought were Chinese (Yuan, Jayaram, and Kassiri 2017). Case One demonstrates how 'China's presence provides alternatives to African nations minus the traditional political interference of Western countries' (Mao 2017). However, this study reveals that they are not the only ones. 'As more states such as India, Brazil and others seek to gain influence on the continent, African countries are at an unprecedented position where their strategic options are better than at any time before'. Offtake agreements thus created stability and much higher predictability in the demand and supply pattern between the South African minerals producers and end users from the non-South African BRICS.

In-depth interviews revealed how executive teams strategically select projects for new mine development. Key success factors were the prevalence of the rule of law, for example, the long-term security of ownership rights, and the availability of essential infrastructure (planes, trains, ports, power supply and roads). In Case Two, the executive responsible for corporate development highlighted the context:

We're not short of opportunities with BRICs partners, as they are the ones who are knocking at our doors. We have a lot of approaches of Chinese and Indian firms who want to become partners and to develop mines... and the Brazilians saw resources in Africa as a big thing, especially copper. So they were aggressively looking for options in South Africa in copper and to a certain extent in coal (Director, Case Two mining company, Johannesburg, Personal communication, April 2013).

Notwithstanding new options, the first thing for the executive team in Case Two was to reduce risk: 'Rio Tinto invested in Guinea. They have started the mining but they cannot get their stuff to the port because of a poor infrastructure' (Director, Case Two mining company, Johannesburg, April 2013). Although listed on the JSE, financial 
matters were not taken directly into consideration at first. The business model utilised immediately focussed on achieving profit:

Whether a country has temptingly great copper or gold to be mined, that's just the beginning of the whole process. The main thing is how you can get that to the market... We needed somebody to help us to place our product; a marketing partner to place our product on the market... (Director, Case Two mining company, Johannesburg, Personal communication, April 2013).

A recurrent problem that emerged in interviews was the potential impermanence of partner commitment and dynamism, notably when it came to new deep level mining projects. In addition, it was crucial 'to call the resources cycle correctly,' not just actualising high earnings during the upswing but also preparing for the inevitable downswing. Feeding the bottom line required agency in the form of studying and engaging with new marketing partners who would hopefully have strategic interests in reliably securing products, confirmed through willingness to sign off-take agreements.

The executive team in Case Two pursued a major transaction, first acquiring a further one-third of the company shares it lacked in 2009. This needed to be followed by the creation of a 50:50 joint venture with the most suitable marketing partner. The executive responsible for corporate development explained the process of selecting the best fit for concluding such a deal:

We did what is called a 'beauty parade'. They [we] would send a letter to all the 40 mining companies in the world to announce the interest to sell. They [the bidders] would then communicate their interest in the deal. The list of interested companies is shortlisted to seven companies. You'll meet with them and then they would reduce the list to three companies. You'll continue discussions with them and reach an agreement... So if you enter a process like that, it's a journey of six months up to a year, where you're selling your shares and re-negotiating. In that process of time you get to know the other party and you are either building or destroying trust. The fellow who'll eventually win this process might like you a lot in the end, because he considers the time he invested not as a waste... (Director, Case Two mining company, Johannesburg, Personal communication, April 2013).

The process remained strongly tied to the search for a risk-averse corporate growth strategy in the sense of 'calling the resource cycle correctly' to protect company assets and employees' jobs, beyond purely aiming at shareholder value. Evidence from the interviews in Case Two suggests a pragmatic or opportunistic problem-solving strategy (Hjorth 2012; Sarasvathy and Venkataraman 2011). How would the new partners deal with low points in the price cycle? For the South African producer, 'contribution to the value chain in our partnership' meant to preserve 'control of the production operation', thus 'driving the production processes up to a point where the product is sellable' (Director, Case Two mining company, Johannesburg, April 2013). Beyond production, cost competitiveness at all stages was an equally salient issue.

In an in-depth interview conducted one month after South Africa had successfully hosted the 5th BRICS Summit in Durban, a director also stressed unpredictability and a complex political environment within the BRICS:

As to strategy thinking within BRICS, sometimes one has to look at the level above. The [Brazilian] government's focus has shifted away to ask [our partner] to keep their money 
and investments in their own country to create growth in Brazil. You cannot counteract in the whole BRICS thing against what is government's focus right now. So sometimes there are overriding things that take you away from the BRICS idea. And that changes from government to government, from CEO to CEO. And sometimes the markets change (Director, CaseTwo mining company, Johannesburg, Personal communication, April 2013).

The quote exemplifies the complex political environment irrespective of individual personalities changing at the top executive levels. With regard to the overriding drivers, the key point from Case Two's perspective was the final validation of the South African player's own power base, which generated the executive team's opportunistic but riskaverse perception of the 'BRICS idea'. The actual contingency, even the unpredictability of governments' agendas or of CEO's agendas - in fact the unpredictability in the 'winwin' preferences of relevant market actors - made the team cautious and aware of their own priorities.

\subsection{Negotiating power relations}

In implementing their strategies, the six South African corporations studied sought long-term arrangements with varied partners. South African executive teams assigned a high value to negotiating preferred terms in such arrangements between individuals at the top level. Yet, teams have to learn continuously and re-adapt their approaches as they often experience limitations in capacity. Agency to act under uncertainty has to be managed.

Various factors such as company size, financial capacity, government support and power relations between most of the South African and their potential BRIC partners are unequal in favour of the BRIC side. Therefore, identifying appropriate stakeholders as partners and negotiating agreements for long-term cooperation remain key challenges for the South African corporations. In particular, they seek to guarantee more stable and long-term contractual arrangements for greater predictability, to safeguard intellectual property to avoid unintended transfer of expertise, and to integrate protective mechanisms to prevent potential future crowding-out competition.

Such balanced agreements between South African market access and BRIC partners' 'resource seeking' or 'market seeking' interests were accomplished through a strategic equity partnership with a Chinese funder and off-taker in Case One, a strategic marketing joint venture with a Brazilian multinational company in Case Two, forms of supplychain collaboration in Case Three, and buyer-supplier agreements with players from each of the BRICS partners in the remaining three cases. There was a notable joint manufacturing venture with an Indian components manufacturer and supplier in Case Six. A majority of the executive teams from the multiple-case study opted to pursue development financing provided by non-South African BRICS players secured through off-take agreements.

The experiences that facilitated competitive growth of their own power base created a broader way forward. In Case Two, it involved assessing resource endowment, completing feasibility studies and organising potential partnership deals with a partner who would take 'control of the production operation'. Identifying a 'beauty queen' out of 40 world leading mining companies implies a high level of self-perception. An 
opportunistic drive to find the perfect fit with respect to non-core competencies is also perceptible. The respondent revealed that the process of 'getting to know the other party [...] either building or destroying trust' involved a contingent process of learning and experimenting. It meant engaging with the world's largest iron ore producer, in fact a competitor in one of the company's core products. Therefore, opportunism in learning how to engage with giants is particularly salient.

Personality and personal commitment were essential in the transaction and the subsequent formation of a marketing joint venture with the Brazilian multinational company in daily operations and at all business levels. It was also a learning process involving taking a risk and articulating and balancing different imperatives due to the different business cultures:

(...) there was a lot of trust built up in the process which lasted also until afterwards. There was a lot of transparency between us, also about their business - where they were going and what opportunities they saw for us. The communication was very good indeed. They said the communication was very, very good! However I have to say that this is personality driven! (Director, Case Two mining company, Johannesburg, Personal communication, April 2013).

In Case Two, arranging mutual transparency and openness in communication at the top level and sharing entrepreneurial rationale and information on African opportunities ranked very high. Successful South African teams that were studied needed to be able to compensate for lack of financial capacity in the new arrangements and where there were conflicts of interest. They compensated through their practical understanding of how to provide the required technology and product or service quality, local market intelligence, and mastery of ventures in Africa that are often vulnerable to high costs due to unpredictability and risk.

South African business interviewees shared concerns over the domestic economic environment in South Africa characterised by infrastructural and bureaucratic challenges (Grant Makokera, Chapman, and Wentworth 2012; Mohamed 2013):

'...It is not easy for foreign investors to come to South Africa. There is a lot of timeconsuming administration and bureaucracy, and it is really difficult to do business here' (Senior executive, Case Six manufacturing company, Johannesburg, March 2013).

Consequently, reliable contracts with South African service providers could be critical for investors from other BRIC members as they were for Western investors. Here, South African companies' agency is manifest in service provision niches. The EPCM provider (Case Four), the OEM (Case Five) and the components manufacturer (Case Six) all exemplified situations that demanded more than straightforward technology transfer and required establishing incentives for the creation of tightly-knit partnerships. Best quality of service provision could then become the basis for obtaining significant product orders from international clients (Wenzel 2016).

Disadvantageous power relations can be turned into strengths. Successful teams learnt not only to turn adversity into opportunity but also how to demonstrate their strengths through flexible problem solving with their BRIC partners. Such teams constantly attempted to become facilitators and key stakeholders in new economic linkages with both customers and suppliers. Consequently, shifts in meaning making (e.g. self-perception; cognitive frames of competition and collaboration; market 
intelligence) have shifted attitudes from a defeatist retreat from rivalry to a sense of achievement in an entrepreneurial spirit of 'getting things done.' Again, the need and the willingness to carry out appropriate entrepreneurial practices and types of agency (e.g. strategic, collaborative, opportunistic) were evident in executive teams' continual search for successful collaboration strategies. These involved firm-to-firm economic diplomacy that resulted in agreements on profitable long-term arrangements.

\subsection{Joint investment in international infrastructure}

Interviews, group discussions, conversations, and observations of phone calls or meetings involving the relatively small minerals logistics provider (Case Three) offered evidence of a growing relationship with a much larger Chinese partner. The partner would financially support the so-called north-south rail corridor linking Maputo (Mozambique), Pretoria and Durban. There is a need to connect the Indian Ocean ports better to deal with bulk transport and fill the empty coal trains coming back from Maputo into South Africa. The planned expansion of Maputo's Matola Coal Terminal, which is already the main gateway from South Africa for Indian coal importers (Director, Case Three, Johannesburg, April 2013) would play a key role here . Consequently, new arrangements could aim at jointly creating anchor connections linked to the rail system and thereby reduce transport time cycles from pit to port.

The opportunities that emerged were both practical and visionary. Case Three developed a business model out of a clear vision, which is characteristic of what we shall call the conductor type of agency. As a result, Chinese importers of chrome and manganese began to invest in the expansion and advancement of rail facilities as well as adjacent warehouses. Feasibility studies were also carried out for smaller joint ventures for investing capital and expertise in the construction of short private railway lines to connect some black-owned mines to the main routes. These mine owners struggle with high fixed costs during low price phases. Their only opportunity for reducing costs and continuing production lies in attracting FDI from end-users. This necessitated the instruments required to spark off long-term contract commitments. This could be described as ring-fencing and going against the conventional flow of supply and demand.

On a ring-fence model with somebody, it can be the lowest cost model, with lowest margins, so that it is sustainable. You ring-fence it with the furnace on the other side in China, and you ring-fence it with the supplier. It is a common model, but I think what we have done is we have forced the model for our own purposes. If you really want sustainability, we get CU1 to sell it to the guys [Chinese steel mills]. CU1 will do a deal with the finance and ring-fence (Director, Case Three minerals logistics company, Johannesburg, Personal communication, April 2013).

Such practices have consequences beyond the micro level of inter-organisational exchanges and collaboration. The associated companies claim to have achieved a shift in the commodity export process from ecologically damaging and costly road transport to cheaper rail transport. Accomplishing this shift requires a niche strategy that calls for skilful balancing through collaboration despite potentially contrasting aspirations. The conductor's strengths lie in considering and proactively experimenting with diverse 
stakeholders' imperatives. Succeeding involves mastering tough learning processes that overcome conventional operational hierarchies. Novel but simple tools have to be found.

Organising what appears to be 'simplicity' and providing effective proximity were tools that allowed minerals suppliers and end users to interact in what Fligstein (2001) has termed 'conceptions of control'. He considers these to be powerful cognitive mechanisms that justify particular activities. Appropriating these conceptions to customers' needs then becomes the basis for spreading contractual and physical anchor connections. In this case, new contracts and rail sidings were supposed to be organised. An entrepreneurial and innovative focus on outcome became essential in settling on a fixed investment. It was also based on the development of relationships sustained through a degree of affection and ambition as well as a will to advance to new entrepreneurial practices of problem solving, and a visionary approach towards an unrealised reality. This also required continuous attention to external macro stimuli. These sustained the conductors' determination to broker an agreement, and the learning process of facilitating new social and material linkages supported the activity. At the micro-level, these linkages also help to 'shift minerals cargo from road to rail' and thus provide greater predictability to the supply chain niche firm.

\section{Conclusion}

South African companies in the 2010s have accomplished substantial goals from their revised corporate development strategies in the BRICS context including constructing new mines, growing new markets for existing products and services, achieving proximity and customer loyalty in new locations, exploring future market potential of such locations, developing and strengthening after-sales services in new markets, and creating cost synergies to compete internationally more effectively. For instance, off-take agreements as well as competitively secured Chinese funding ensured the survival and profitability of new and current mining projects, thus stabilising employment despite recent sweeping retrenchments in platinum mining elsewhere.

Ethnographic research is suitable for exploring and understanding what triggers trial and error methods, unlearning the past, and observing how learning to revise entrepreneurial practices can generate higher predictability in supply or demand. Predictability can no longer be based on the structural bureaucratic features of organisations as outlined by Chandler (1977). The empirical evidence presented here results from a qualitative approach using different methods and emerged from a small sample of South African firms. Findings cannot necessarily be generalised to the broader population of private or listed companies. However, they are potentially indicative of how decision-makers perform in the present uncertain economic environment.

Drawing from a larger study, this paper has suggested three distinct types based on varied conditions that generate competitive agency. Each of them creates (social) value from negotiating, investing in, and in particular, practicing significant inter-organisational arrangements. They all hinge on the difficult process of constructing sociotechnical linkages and profitable relationships that have become essential for success. Competitive agency is created through contextual conditions, subjective reflexivity, as 
well as ongoing practices and arrangements. It means taking on target-oriented capacity to generate desired effects in an uncertain environment.

The empirical evidence found in the study confirms the need to advance the theoretical understanding of agency, and thereby, the analytical power of the concept. Competitive agency, in its narrowest sense, permits executive teams to profitably create and distribute value-added commodities, products and services. In its wider sense, it actualises value for the enterprise, its stakeholders, and the society. Entrepreneurial methods can fortify competitive agency to negotiate interests and to overcome perceived impediments to growing business proactively. Organisational entrepreneurship is thus (re)defined as a proactive method of human problem-solving and a practical form of organising human and material arrangements (Hjorth 2012; Sarasvathy and Venkataraman 2011). Reflexive searching, investing into and accomplishing new arrangements can generate the creative power to turn competitive agency and the new diversified linkages it creates into value for the South African players.

Ethnographic research allows one to trace the different capacities appropriate for distinct types of agency. African agents have real strengths. Often, they are too superficially characterised as subordinate, dominated or marginal. They can distinguish between tolerating or adapting to dominance, finding new combinations of engagement, resisting, and changing situations, or even exercising dominance in certain areas. This has been characterised through examining meso-level social orders, which reside at every level of both collective and individual interactions (Fligstein and Vandebroeck 2014).

We suggest here that entrepreneurship should be defined in a way that explores teams' entrepreneurial activities rather than the traits of individuals. Such activities may best be defined as forging a node in a gateway between South Africa and BRIC countries. Successful companies can also shape the gateway physically and through human linkages. South Africa, therefore, has the potential to reap the benefits, political and otherwise, of such a gateway function as well as securing seriously needed employment in an age of global economic volatility.

\section{Notes}

1. The multiple-case study purposely focussed on managers and officials. These included individuals with the job title Chief Executive Officer (CEO); Managing Director (MD), Chief Operating Officer, Chief Financial Officer (CFO); Director of Corporate Affairs, or Director of Corporate Development. All participants in the research act as members of the executive teams with their very diverse styles of leading their businesses in a dynamic environment. Executive teams normally operate one level below the board but in small companies, they act as members of the board.

2. India is not listed in Table Three as it ranks as a relatively minor producer: India's gold production was estimated to be 1.6 metric tons in 2017 (2.2 in 2012), while its estimated gold reserves stood at 557.8 metric tons in 2017.

3. China also absorbed more than $60 \%$ of the world's traded iron ore, the fourth biggest commodity on sale from South Africa (Baxter 2016).

\section{Acknowledgements}

The authors would like to thank the interviewees in Johannesburg for their valuable insights, effort and time invested in supporting the research process. 


\section{Disclosure statement}

No potential conflict of interest was reported by the authors.

\section{Funding}

This work was supported by the Swiss National Science Foundation under Grant number [10001A 143234].

\section{References}

Barnes, J., and M. Morris. 2008. "Staying Alive in the Global Automotive Industry: What Can Developing Economies Learn from South Africa about Linking into Global Automotive Value Chains?" The European Journal of Development Research, 20 (1): 31-55. doi:10.1080/ 09578810701853157.

Bhorat, H., A. Cassim, and A. Hirsch. 2014. "Policy Co-Ordination and Growth Traps in a Middle-Income Country Setting: The Case of South Africa." In The Practice of Industrial Policy Government-Business Coordination in Africa and East Asia, edited by J. Page and T. Finn, 211-233. Oxford: Oxford University Press.

Black, A. 2014. "The Evolution and Impact of Foreign Direct Investment into South Africa since 1994." In The Oxford Companion to the Economics of South Africa, edited by H. Bhorat, A. Hirsch, R. Kanbur, and M. Ncube, 95-101. Oxford: Oxford University Press.

Bohler-Muller, N., and F. A. Kornegay Jr. 2013. "Prologue." In Laying the Brics of a New Global Order: From Yekaterinburg 2009 to Ethekwini 2013, edited by F. Kornegay Jr and N. BohlerMuller, xxi-viii. Pretoria: African Institute of South Africa.

Çakir, M., and A. Kabundi. 2017. "Transmission of China's Shocks to the BRICS Countries." South African Journal of Economics 85 (3): 430-454. doi:10.1111/saje.2017.85.issue-3.

Capps, G. 2012. "Victim of Its Own Success? The Platinum Mining Industry and the Apartheid Mineral Property System in South Africa's Political Transition." Review of African Political Economy 39 (131): 63-84. doi:10.1080/03056244.2012.659006.

Carmody, D. P. 2013. The Rise of the Brics in Africa: The Geopolitics of South-South Relations. London: Zed Books.

Chamber of Mines. 2015. Chamber Presentation on the State of the Coal Sector in 2015. Johannesburg.

Chamber of Mines. 2016. Mining in South Africa: The Challenges and the Opportunities: Chamber of Mines of South Africa. Johannesburg.

Chandler, A. D., Jr. 1977. The Visible Hand: The Managerial Revolution in American Business. Cambridge, MA: Harvard University Press.

Draper, P., and M. Qobo. (2015). South Africa Needs a Concrete Brics Strategy. Accessed http:// www.saiia.org.za/opinion-analysis/south-africa-needs-a-concrete-brics-strategy.

Fine, B., and Z. Rustomjee. 1996. The Political Economy of South Africa: From Minerals Energy Complex to Industrialisation. London: C. Hurst \& Co. Publishers.

Fligstein, N. 2001. The Architecture of Markets: An Economic Sociology of Twenty-First-Century Capitalist Societies. Princeton, NJ: Princeton University Press.

Fligstein, N., and D. Vandebroeck. 2014. "The Frenzy of Fields: An Interview with Neil Fligstein on Field-Theory and Social Skill.” Irish Journal of Sociology 22 (1): 107-129. doi:10.7227/ IJS.22.1.8.

Freund, B. 2013. "Swimming against the Tide: The Macro-Economic Research Group in the South African Transition: 1991-94.” Review of African Political Economy 40 (138): 519-536. doi:10.1080/03056244.2013.854038.

Fundira, T. 2011. Trade at A Glance: A Comparative Analysis of the BRICS Countries. Stellenbosch: Tralac Trade Law Centre. 
Gelb, S. 1991. “South Africa's Economic Crisis: An Overview.” In South Africa's Economic Crisis, edited by S. Gelb, 1-31. Cape Town: New Africa Books.

Gelb, S. 2010. "Macroeconomic Policy and Development: From Crisis to Crisis." In Development Dilemmas in Post-Apartheid South Africa, edited by W. Freund and H. Witt, 32-61. Pietermaritzburg: University of KwaZulu-Natal Press.

Grant Makokera, C. 2015. "South African Economic Diplomacy-Engaging the Private Sector and Parastatals.” Institute for Security Studies Papers 2015 (280): 16.

Grant Makokera, C., G. Chapman, and L. Wentworth. 2012. Top 10 Business Constraints in SADC: An Analysis of Business and Investment Climate Surveys. Johannesburg: South African Institute for International Affairs.

Hirsch, A. 2005. Season of Hope: Economic Reform under Mandela and Mbeki. Scottsville: University of KwaZulu-Natal Press and International Development Research Centre (IDRC).

Hjorth, D. 2012. "Introduction: Entrepreneurship in Organisational Contexts." In Handbook on Organisational Entrepreneurship, edited by D. Hjorth, 1-19. London: Edward Elgar.

Jones, A., and J. T. Murphy. 2011. "Theorizing Practice in Economic Geography: Foundations, Challenges, and Possibilities." Progress in Human Geography 35 (3): 366-392. doi:10.1177/ 0309132510375585.

Kaplan, D. E. 2015. "Structural Change and Industrial Development in the Brics." In The Structure and Performance of Manufacturing in South Africa, edited by W. Naudé, A. Szirmai, and N. Haraguchi, 244-263. Oxford: Oxford University Press.

Makgetla, N. 2011. "The Controversy about Economic Growth." In Essence of the Inherited Structure, edited by B. Turok, 9-22. Johannesburg: Jacana.Accessed

Manufacturing Circle. 2017. Map to a Million Jobs in a Decade. Manufacturing Accessed Circle. https://www.tips.org.za/images/Map_to_a_million_new_jobs_in_a_decade_Manufacturing Circle_November_2017.pdf

Mao, N. 2017. Is South Africa a Gateway for China's Investment in Africa? Accessed https:// www.howwemadeitinafrica.com/south-africa-gateway-chinas-investment-africa/58479/.

Minerals Council. 2018a. Gold: Key Facts and Figures. Accessed http://www.mineralscouncil.org. $\mathrm{za} /$ sa-mining/gold.

Minerals Council. 2018b. Platinum: Key Facts and Figures. Accessed http://www.mineralscoun cil.org.za/sa-mining/platinum.

Misra, K. 2000. Understanding Mineral Deposits. Dordrecht: Kluwer Academic Netherlands.

Mohamed, S. 2013. "The International Economic Crisis and Its Impact on Employment and Poverty Alleviation in South Africa." In State of the Nation South Africa, 2012-2013: Addressing Inequality and Poverty, edited by P. Udesh, G. Hagg, F. Nyamnjohand, and J. Jansen, 663-676. Cape Town: HSRC Press.

Morris, M., and J. Barnes. 2014. "The Challenges to Reversing the Decline of the Apparel Sector in South Africa." In International Conference on Manufacturing-Led Growth for Employment and Equality in South Africa.

Naudé, W., A. Szirmai, and N. Haraguchi. 2015. Structural Change and Industrial Development in the Brics. Oxford: Oxford University Press.

Qobo, M. 2010. "Refocusing South Africa's Economic Diplomacy: The 'African agenda' and Emerging Powers.” South African Journal of International Affairs 17 (1): 13-28. doi:10.1080/ 10220461003763833.

Rodrik, D. 2008. "Understanding South Africa's Economic Puzzles." Economics of Transition 16 (4): 769-797. doi:10.1111/ecot.2008.16.issue-4.

Sandrey, R., and H. G. Jensen. 2012. South Africa - How Do We Become a BRIC? Stellenbosch: Trade Law Centre for Southern Africa.

Sarasvathy, S. D., and S. Venkataraman. 2011. "Entrepreneurship as Method: Open Questions for an Entrepreneurial Future." Entrepreneurship Theory and Practice 35 (1): 113-135. doi:10.1111/etap.2011.35.issue-1.

Schatzki, T. R. 2006. “On Organizations as They Happen.” Organization Studies 27 (12): 18631873. doi:10.1177/0170840606071942. 
Statista 2018. Durchschnittliche produktionskosten pro unze gold weltweit nach region im jahr 2016 (in us-dollar). Accessed https://de.statista.com/statistik/daten/studie/461100/umfrage/ durchschnittliche-produktionskosten-pro-unze-gold-weltweitnach-region/.

STATSSA 2016. Media Statement: Quarterly Employment Statistics. Accessed http://www.statssa. gov.za/?p=8582.

Terreblanche, S. 2012. Lost in Transformation: South Africa's Search for a New Future since 1986. Johannesburg: KMM Review Publishing Company.

Tregenna, F. 2008. Sectoral Engines of Growth in South Africa: An Analysis of Services and Manufacturing. Helsinki: UNU World Institute for Development Economics Research.

Valsamakis, A. 2012. "The role of South African business in South Africa's Post-Apartheid Economic Diplomacy.” PhD diss., University of Birmingham.

Verhoef, G. 2011. “The Globalisation of South African Conglomerates, 1990-2009.” Economic History of Developing Regions 26 (2): 83-106. doi:10.1080/20780389.2011.625242.

Wenzel, N. 2014. "Brics Corporates: In Collaboration or in Competition in Africa? Case Studies from the South African Mining Industry." South African Journal of International Affairs 21 (3): 431-448. doi:10.1080/10220461.2014.969765.

Wenzel, N. 2016. "South AfricanCorporations in Brics: New Waves of Entrepreneurial Thinking?" In Emerging Powers in Africa - A New Wave in the Relationship?, edited by J. Van der Merwe, I. Taylor, and A. Arkhangelskaya, 177-197. Cham: Palgrave Macmillan.

Wenzel, N. Forthcoming."Competitive Agency for Surviving in the BRICS? Practices in the South African Mining and Manufacturing Industry." PhD diss., University of Fribourg.

Wenzel, N., O. Graefe, and B. Freund. 2013. "Competition and Cooperation: Can South African Business Create Synergies from BRIC+S in Africa?” African Geographical Review 32 (1): 14-28. doi:10.1080/19376812.2012.751856.

Yuan, S. I., K. Jayaram, and O. Kassiri. 2017. Dance of the Lions: How are Africa and China Engaging, and How Will the Partnership Evolve? McKinsey \& Company. 